Maria Tomczak

(Poznań-Gniezno)

https://orcid.org/0000-0001-7293-2083

\title{
DZIEKANKA/TIEGENHOF - STAN WIEDZY O FUNKCJONOWANIU ZAKŁADU PODCZAS II WOJNY ŚWIATOWEJ
}

\begin{abstract}
The article discusses the current state of research on the wartime fates of the mental institution in Gniezno known as Dziekanka, offering a number polemical views with respect to previous publications concerning the issue, in particular its association with Aktion T4, the nature of the establishment and the number of victims.
\end{abstract}

\section{Keywords}

World War II, Dziekanka/Tiegenhof, Wartheland, Aktion T4, pseudo-euthanasia

W kulturze europejskiej (i nie tylko) choroba psychiczna była przez wieki traktowana jako najgorsza z możliwych. Ataki szaleństwa odczłowieczały chorego, czyniły go uciążliwym dla otoczenia, nierzadko wręcz niebezpiecznym. To szaleństwo nie wyglądało jak „prawdziwa” choroba, szukano więc innych jego przyczyn, takich jak urok czy opętanie. W XIX w. uznano, że większość dolegliwości psychicznych ma charakter dziedziczny, co sprawiało, że choroba stygmatyzowała całe rodziny.

Diagnozowanie i leczenie chorób psychicznych było przez wieki bardzo trudne. Jeszcze przed II wojną światową nie wszędzie uznawano psychiatrię za dziedzinę medycyny. Nie dysponując współczesną aparaturą, trudno było znaleźć przyczynę choroby. Nie znano też używanych dziś powszechnie leków, a środki, jakie aplikowano chorym, bardziej przypominały tortury niż leczenie. 
W bardziej odległej przeszłości podejmowane były z reguły próby pozbywania się chorych z przestrzeni publicznej - wywożenia ich lub izolacji. W średniowieczu praktykowano m.in. zamykanie chorych jak przestępców w lochach lub wieżach miejskich, niekiedy także wysyłanie osób dotkniętych szaleństwem w podróż w nieznane statkiem czy innymi środkami transportu. To wówczas w kulturze europejskiej pojawił się motyw statku głupców ${ }^{1}$.

Od dawna istniały też zakłady, czy też miejsca odosobnienia, przeznaczone wyłącznie dla osób cierpiących na różne odmiany szaleństwa. Także one nie różniły się z reguły od więzień. Nikt się chorymi nie opiekował, a jedynym celem izolacji było pozbycie się ich, usunięcie $\mathrm{z}$ widoku. Zakłady łączące funkcję izolacyjną z minimalną choćby opieką na większą skalę zaczęto budować w Europie dopiero w XIX w. Stały się potrzebne nie ze względu na zwiększoną liczbę zachorowań, ale z powodu rozrastania się miast. Gęstość zaludnienia, dyscyplina niezbędna do funkcjonowania, a także zmiana struktury rodziny $z$ wielopokoleniowej na mniejszą, złożoną z rodziców i dzieci, sprawiały, że osoby chore psychicznie w miastach uznawano za problem. Zakłócały porządek i nie miał się nimi kto opiekować. Były więc wyłapywane przez policję i przekazywane do zakładów. W efekcie potrzeba było coraz więcej i coraz większych zakładów. W Europie Zachodniej powstawały placówki psychiatryczne mogące przyjmować od 500 do nawet 2000 pacjentów. Gromadzenie chorych w jednym miejscu, przy nader ograniczonych możliwościach leczenia, tworzyło nowe problemy. Pacjenci przebywali w zakładach bardzo długo (często do końca życia), co nie tylko generowało koszty, ale też powodowało, że mimo przekazywania do użytku coraz to nowych i większych zakładów, ciągle brakowało miejsc.

W takim kontekście spojrzeć można na mordowanie chorych psychicznie w III Rzeszy. Podjęte przez władze nazistowskich Niemiec działania, nazywane eufemistycznie eutanazją, doprowadziły do śmierci dziesiątek, a może nawet setek tysięcy osób. Ich śmierć miała służyć ograniczeniu wydatków oraz „ulepszeniu" rasy aryjskiej. Zbrodnia ta, nazywana Akcją T4, dokonywana była także na ziemiach polskich, wcielonych do Rzeszy. Jednym z zakładów, w których mordowano chorych, była gnieźnieńska Dziekanka, przemianowana przez Niemców na Tiegenhof.

Celem opracowania jest próba podsumowania dotychczasowego stanu wiedzy o wojennej historii gnieźnieńskiego zakładu. Przedstawione zostaną kolejno geneza Akcji T4, zbrodnie dokonane w Dziekance/Tiegenhofie oraz o charakter tego zakładu. Podjęta zostanie również próba udzielenia odpowiedzi na pytanie o liczbę ofiar.

${ }^{1}$ Najsłynniejsze z nich to poemat Sebastiana Brandta z 1494 r. pt. „Daß Narrenschyff ad Narragoniam” oraz obraz Hieronima Boscha „Statek głupców”, również z końca XV w. 


\section{SYTUACJA CHORYCH PSYCHICZNIE W NIEMCZECH W PIERWSZEJ POŁOWIE XX W.}

Żeby zrozumieć, jak w okresie III Rzeszy mogło dojść do realizacji makabrycznego pomysłu zabijania osób chorych psychicznie, należy cofnąć się o kilka dziesięcioleci, w ciągu których w Niemczech dokonywał się proces ich powolnego odczłowieczania. Nie był to przy tym jakiś przemyślany plan, którym ktoś kierował, ale raczej szereg stosunkowo drobnych kroków, niekiedy wręcz podejmowanych w dobrej wierze, które jednak w sumie doprowadziły do tragedii.

O początkach tego procesu już wspomniałam. Rozwój miast i industrializacja przyczyniły się do subiektywnego wyolbrzymienia problemu chorób psychicznych. Działo się tak zwłaszcza w Niemczech, gdzie gwałtowność procesów modernizacyjnych pociągała za sobą również gwałtowne narastanie towarzyszących im zjawisk niekorzystnych.

Ważną cezurę w sposobie postrzegania chorych psychicznie stanowiła I wojna światowa. Na jej codzienny koszmar wielu żołnierzy reagowało napadami drgawek, paraliżem, utratą mowy itp. Byli oni wysyłani do zakładów psychiatrycznych, gdzie traktowano ich jak symulantów i nakłaniano wszelkimi dostępnymi sposobami do powrotu na front. Jednym $\mathrm{z}$ efektów takiego postępowania stała się zmiana obiektu leczenia psychiatrycznego: w jego centrum nie znajdował się już cierpiący człowiek, ale ponadjednostkowa struktura społeczna: państwo czy naród, którego wysiłek wojenny mógł zostać osłabiony. Celem nadrzędnym przestało być leczenie, a stało się dyscyplinowanie pacjentów. Chorzy psychicznie zostali de facto zrównani w statusie z przestępcami, czy szerzej - z osobami z marginesu społecznego.

Nie tylko żołnierze z urazami psychicznymi, ale także inni pacjenci zakładów psychiatrycznych stali się ofiarami wojny. W warunkach nałożonej na Niemcy blokady i kłopotów z zaopatrzeniem umierali zwłaszcza z niedożywienia. W samych Niemczech liczbę zmarłych $\mathrm{z}$ tego powodu w latach 1914-1918 szacuje się na ponad 70 tysięcy ${ }^{2}$. Mimo to w kraju zapanowało przekonanie, że wobec trudności finansowych i zaopatrzeniowych błędem było karmienie „pustych skorup ludzkich”.

W takiej atmosferze w międzywojennych Niemczech zaczęto poszukiwać skutecznych rozwiązań problemu. Metody najbardziej radykalne zaproponowali w 1920 r. prawnik Karl Binding i lekarz Alfred Hoche. Opublikowana przez nich praca pt. „Die Freigabe zur Vernichtung lebensunwerten Lebens. Ihr Maß und ihre Formen” była opowiedzeniem się za możliwością zabijania osób nieuleczalnie chorych psychicznie. To tam właśnie po raz pierwszy pojawiło się, przejęte potem przez narodowych socjalistów, sformułowanie, które można przetłumaczyć jako

\footnotetext{
${ }^{2}$ Schmuhl 2000, s. 384.
} 
„życie niewarte przeżycia” (lebensunwertes Leben). Warto dodać, że w momencie wydania opracowanie to wydawało się wielu nazbyt radykalne, a zaproponowana metoda niemożliwa do zastosowania.

W latach 20. XX w. podjęto się reformy lecznictwa psychiatrycznego, która przewidywała szereg postępowych posunięć, np. stworzenie systemu opieki otwartej, co miało zapobiegać przepełnieniu zakładów. Wielu pacjentom ordynowano terapię przez pracę, co uwalniało ich do długotrwałej przymusowej bezczynności. Skrócono też o połowę czas przebywania chorych w zakładach zamkniętych.

Zarazem jednak reforma obejmowała założenia potencjalnie niebezpieczne. Dotyczy to zwłaszcza terapii przez pracę, która dzieliła chorych na zdolnych i niezdolnych do pracy. Podkreślano przy tym, że celem takiego sposobu postępowania jest przywracanie chorych psychicznie wspólnocie narodowej. Pacjent miał się jeszcze silniej niż dotąd podporządkować oczekiwaniom społecznym. Jeśli tego nie robił, stosowano wobec niego środki dyscyplinujące ${ }^{3}$.

Podejście takie wzmacniały jeszcze poważnie traktowane ustalenia specjalistów z dziedzin uważanych wówczas za naukowe. Karierę robiła zwłaszcza tzw. higiena ras, zapoczątkowana przez Alfreda Ploetza. Do jej czołowych przedstawicieli należeli w republice weimarskiej Ernst Rüdin, Max von Gruber, Fritz Lenz i Eugen Fischer ${ }^{4}$. Teoria ta, bazująca na tzw. darwinizmie społecznym, wydawała się podpowiadać naukowe rozwiązania dla popadającej w coraz większe kłopoty finansowe publicznej służby zdrowia. Złotym środkiem miała być dobrowolna sterylizacja osób niedorozwiniętych, cierpiących na różne odmiany padaczki, psychopatów i innych dziedzicznie obciążonych.

Warto przy tym nadmienić, że zwolennicy eugeniki, higieny rasowej i innych podobnych pseudonauk zyskali silną pozycję już w końcowym okresie republiki weimarskiej. Publikowane przez nich prace były szeroko dyskutowane nie tylko w Niemczech, ale także w innych krajach Europy. Ich teorie mogły jednak znaleźć pełne zastosowanie dopiero po przejęciu władzy przez nazistów, którzy połączyli ze sobą cele ekonomiczne i rasowe, czyli oszczędności i ulepszanie rasy poprzez stopniową eliminację chorób dziedzicznych. Rozpoczęto od przymusowej sterylizacji osób chorych psychicznie. W styczniu 1940 r. na polecenie Hitlera uruchomiono tzw. Akcję T4, tzn. zabijanie pacjentów psychiatrycznych za pomocą gazu. W wybranych zakładach zbudowano komory gazowe i krematoria, w których od stycznia 1940 do sierpnia 1941 r. zamordowano ponad 70 tysięcy osób. Nazwa akcji pochodzi od adresu jej berlińskiej centrali - Tiergartenstrasse 4 . Akcja prowadzona była bez podstaw prawnych i - mimo braku jakiegoś zde-

\footnotetext{
3 Ibidem, s. 383 i nn.

4 Więcej zob. Musielak 2014, s. 14 i n.
} 
cydowanego sprzeciwu społecznego w tej sprawie - starannie ukrywana przed opinią publicznąa

Akcja T4 zakończyła się oficjalnie w sierpniu $1941 \mathrm{r}$. Zadecydował o tym również Hitler, po tym jak mordowanie psychicznie chorych zdemaskował i napiętnował w swym kazaniu katolicki biskup Münsteru Clemens August von Galen. Władze nazistowskie uznały wówczas, że w obliczu toczonej właśnie kampanii na Wschodzie lepiej będzie wyciszyć całą sprawę, by uniknąć niepotrzebnego podgrzewania nastrojów społecznych ${ }^{6}$. Nie oznaczało to jednak kresu zabijania chorych psychicznie. Akcję kontynuowano, ale wolniej i jeszcze bardziej dyskretnie: przedawkowując leki, głodząc czy zwyczajnie zaniedbując chorych. W historiografii niemieckiej nazwano to drugą fazą Akcji T4. Prowadzona była nie tylko w zakładach psychiatrycznych umiejscowionych w tzw. Starej Rzeszy, ale od $1941 \mathrm{r}$. również na ziemiach polskich wcielonych do Rzeszy. Zakładem wzorcowym w Kraju Warty stała się gnieźnieńska Dziekanka, przemianowana na Tiegenhof.

\section{2. ŹRÓDŁA WIEDZY O LOSACH DZIEKANKI/TIEGENHOFU}

Wojenna historia gnieźnieńskiej Dziekanki przez całe dziesięciolecia interesowała jedynie psychiatrów. Podstawę wiedzy na ten temat stanowił raport sporządzony przez pierwszego po 1945 r. dyrektora zakładu Jana Gallusa. Raport ten, przygotowany bezpośrednio po wojnie, oparty został na dokumentach (niekompletnych, nienależycie zabezpieczonych i w następnych dziesięcioleciach w znacznej mierze bezpowrotnie zaginionych) oraz na relacjach polskiego personelu medycznego i koncentrował się na pierwszych miesiącach wojny. Gallus drobiazgowo opisał zagładę zastanych przez Niemców pacjentów Dziekanki. Znacznie mniej uwagi poświęcił natomiast późniejszym pacjentom Zakładu. Wspomniał, że byli to głównie Niemcy i że wielu z nich było celowo doprowadzanych do śmierci ${ }^{7}$. Ustalenia Gallusa były przez wiele lat powielane przez innych autorów polskich, co ciekawe - również lekarzy, a nie historyków ${ }^{8}$.

Nieco więcej światła na tragedię, jaka rozegrała się na terenie Zakładu, a właściwie na jej aspekt organizacyjny, rzuciła publikacja Volkera Rießa o początkach niszczenia „życia niewartego przeżycia” w Wielkopolsce i na Pomorzu?. Autor opracowania wykorzystał niemieckie dokumenty archiwalne, zeznania polskiego personelu medycznego oraz wcześniejsze opracowania niemieckie i polskie. I on

\footnotetext{
${ }^{5}$ Szerzej na temat Akcji T4 zob. Aly 2015.

${ }^{6}$ Zob. Tomczak 2016.

7 Gallus 1949.

${ }^{8}$ Zob. Choćby Jaroszewski 1993; Jaska-Piotrowski, brw.

${ }^{9}$ Rieß 1995.
} 
skoncentrował się jednak na pierwszych miesiącach tragedii, dodając do dotychczasowej wiedzy opis procesu podejmowania decyzji politycznych.

Dopiero praca młodego niemieckiego historyka Enno Schwankego ${ }^{10}$ podjęła temat bardziej kompleksowo, co wzbudziło także w Polsce większe zainteresowanie odległą już historią. Co ciekawe, Schwanke oparł swe badania głównie na dokumentach polskich: zebranych jeszcze w latach 40. przez Główną Komisję Badania Zbrodni Hitlerowskich relacjach polskiego personelu medycznego. Zostały one spisane, przetłumaczone na język niemiecki i przesłane dla celów procesowych. Dzisiaj są dostępne w Archiwum Państwowym w Ludwigsburgu.

Spośród opracowań polskich na uwagę zasługują: praca zbiorowa pt. „Medycyna na usługach systemu eksterminacji ludności w Trzeciej Rzeszy i na terenach okupowanej Polski” pod red. G. Łukomskiego i G. Kucharskiego ${ }^{11}$ oraz opublikowana w 2016 r. monografia wieloautorska „Bezużyteczni. Studia nad losami chorych i upośledzonych psychicznie w okresie rządów nazistowskich”"12. W pierwszym tomie na uwagę zasługuje zwłaszcza opracowanie Marii Fiebrandt poświęcone losom Tiegenhofu i wykorzystujące, podobnie jak praca Schwankego, zgromadzone w Ludwigsburgu materiały archiwalne ${ }^{13}$. Publikacja druga, badająca przede wszystkim kulturowe aspekty zagłady, zawiera m.in. informację o specjalistycznym oddziale dziecięcym ${ }^{14}$ oraz informację o notesach, przekazanych do $\mathrm{Mu}$ zeum Martyrologicznego w Żabikowie i zawierających listę zmarłych pacjentów $Z_{\text {Zakładu }}{ }^{15}$. To nowo pozyskany, niezwykle interesujący dokument. Zapiski w notesach były prowadzone skrupulatnie przez kogoś, kto pracę w Zakładzie rozpoczął przynajmniej na początku 1932 r., i kto miał najwyraźniej dostęp do dokumentacji pacjentów. Cel tych zapisków jest niejasny. Autorowi/autorce zapisków nie chodziło przecież, przynajmniej początkowo, o dokumentowanie zbrodni. Takich nie było w latach 1932-1939, kiedy Dziekanka cieszyła się renomą zakładu z najniższą śmiertelnością w Polsce, a może nawet w Europie. Wydaje się to potwierdzać odnotowana lista zmarłych. Było ich łącznie 591, co daje średnio nieco ponad 70 zmarłych na rok. Dzisiaj liczba ta wydaje się ogromna, jednak oceniając ją, trzeba brać pod uwagę ówczesny stan psychiatrii. Jak już wspomniałam, zakłady psychiatryczne były w mniejszym stopniu placówkami leczniczymi, a w większym „przechowalniami” dla uciążliwych dla otoczenia pacjentów. Pobyty w Zakładach trwały z reguły długo i kończyły się śmiercią pacjenta. Zapiski pokazują, że okres wojenny przyniósł znaczący wzrost ofiar śmiertelnych. Ich liczba stałe rosła i wy-

\footnotetext{
${ }^{10}$ Schwanke 2015a.

${ }^{11}$ Łukomski i Kucharski 2011.

12 Gajewska, Tomczak i in. 2016.

13 Fiebrandt 2011.

${ }^{14}$ Schwanke 2016.

15 Zob. Ziółkowka 2016.
} 
nosiła kilkaset osób rocznie, co pokazuje jasno, że w Zakładzie doszło do działań zbrodniczych.

Pewne informacje o Dziekance/Tiegenhofie znaleźć można także w innych publikacjach zbiorowych, zwłaszcza w pracy „Medycyna w cieniu nazizmu”, wydanej pod redakcją Michała Musielaka i Katarzyny B. Głodowskiej ${ }^{16}$, gdzie znalazło się m.in. napisane przez wspomnianego już E. Schwankego opracowanie na temat Tiegenhofu, będące w znacznej mierze polskojęzycznym streszczeniem jego książ$\mathrm{ki}^{17}$. Informacje przydatne do odtworzenia pewnych szczegółów z dziejów zakładu znaleźć można także w pracy pod red. T. Nasierowskiego, T. Herczyńskiej i D.M. Myszki z 2012 r. $^{18}$

\section{PIERWSZY ETAP: ZAGŁADA MASOWA}

Niemcy zajęli gnieźnieńską Dziekankę 11 września 1939 r. W zakładzie znajdowało się wówczas 1172 pacjentów, rozmieszczonych w 21 pawilonach. Jednym z pierwszych działań podjętych przez Niemców było podzielenie pacjentów wg narodowości. Dokonywał tego dr Banse, który przybył do Dziekanki 18 października, prosto ze zlikwidowanego wcześniej zakładu psychiatrycznego w Owińskach. Przed przybyciem do Kraju Warty był dyrektorem pomorskiego zakładu Ueckermünde. Z jego sprawozdania, na które powołuje się V. Rieß, wynika, że w ciągu pierwszego miesiąca okupacji liczba pacjentów zmniejszyła się nieznacznie - do 1136. Było to zapewne zarówno efektem zgonów, jak i faktu, że w obliczu rozpoczynającej się okupacji część rodzin zdecydowała się odebrać swoich krewnych. W sprawozdaniu Banse podał, że wśród pacjentów znajdowało się 93 Volksdeutschów, ok. 150 osób pochodzących z Ukrainy i 425 z terenów Lwowa i okolic. Spośród tych ostatnich 98 pochodziło z niemieckiej, a 312 z rosyjskiej sfery wpływów; w przypadku 15 osób nie udało się określić przynależności narodowej. Do tego doszło jeszcze 160 osób pochodzenia żydowskiego, w większości z okręgu lwowskiego. Pozostali uznani zostali za Polaków ${ }^{19}$.

Nie wiadomo, $\mathrm{w}$ jaki sposób dokonywano selekcji. Wiadomo natomiast, że jednym z celów niemieckiej polityki narodowościowej na ziemiach polskich było „odzyskiwanie” osób pochodzenia niemieckiego. Poddawano więc ludzi przeglądom rasowym, celem wpisania na „niemiecką volkslistę". Choć w obliczu zamiarów eksterminacyjnych wydaje się to absurdalne, to jednak przeglądy takie organizowano $\mathrm{w}$ pierwszych miesiącach wojny także we wszystkich przejmowanych

\footnotetext{
16 Musielak i Głodowska 2015.

17 Schwanke 2015b.

18 Nasierowski, Herczyńska, Myszka 2012.

19 Rieß 1995, s. 312-313.
} 
przez Niemców zakładach psychiatrycznych. W Dziekance przegląd taki miał miejsce już w październiku 1939 r. Nieco później do Zakładu przywieziono także uznanych za Volksdeutschów pacjentów z Kościana ${ }^{20}$.

Krótko po wyjeździe dra Bansego zwolniono większość polskiego personelu medycznego. Zgodnie z wyliczeniami Jana Gallusa było to ok. 250 osób ${ }^{21}$. Na stanowisku pozostał jednak dotychczasowy dyrektor Dziekanki, Wiktor Ratka. Ratka był z pochodzenia Ślązakiem. Kierownictwo Zakładu przejął w 1934 r. i do wojny kontynuował wdrażanie postępowych metod leczniczych wprowadzonych przez poprzednika dra Aleksandra Piotrowskiego. Po wkroczeniu Niemców wystąpił o przyznanie obywatelstwa niemieckiego i stał się zwolennikiem pseudoeutanazji chorych psychicznie. Podobnie postąpił dr Stefan Galon, którego Ratka mianował swoim zastępcą ${ }^{22}$. Pozostałym w zakładzie pracownikom zakazał posługiwania się językiem polskim, nawet $w$ rozmowach między sobą. Zostali zmuszeni do złożenia przysięgi, że nikomu nie powiedzą o tym, co będzie się działo w zakładzie. Za jej złamanie grozić miało odesłanie do obozu koncentracyjnego ${ }^{23}$. Mniej więcej w tym samym czasie władze kraju Warty zakazały dalszego zwalniania chorych ${ }^{24}$.

Pierwszy etap zagłady psychicznie chorych, realizowany nie tylko w Dziekance, ale we wszystkich zakładach psychiatrycznych wcielonej do Rzeszy Wielkopolski, która 29 stycznia 1940 r., po zmianach terytorialnych przekształcona została w Okręg Rzeszy Kraj Warty (Reichsgau Wartheland), nie stanowił jeszcze części Akcji T4, jak to sugeruje w swej pracy M. Jaska ${ }^{25}$. Jego inicjatorami i organizatorami były władze prowincji, na czele z samorządem Okręgu (Gauselbstverwaltung) i namiestnikiem Rzeszy Arturem Greiserem. Inaczej niż w prowadzonej na terytorium Niemiec Akcji T4, która przynajmniej formalnie służyła celom ideologicznym, na ziemiach polskich wcielonych do Rzeszy cele były czysto utylitarne: pozbycie się kłopotu i pozyskanie budynków na potrzeby wojska. Ważne było i to, że ambitny Greiser tworzył wzorcowy okręg (Mustergau), w którym na własną rękę wdrażał wszystkie założenia ideowe narodowego socjalizmu. A ponieważ jednym $\mathrm{z}$ nich było wyeliminowanie osób psychicznie chorych, stworzył w tym celu odpowiednie instytucje. I tak w ramach samorządu Okręgu powstał wydział pod enigmatyczną nazwą Opieka zdrowotna i ćwiczenia fizyczne (Gesundheitswesen

${ }^{20}$ Lilienthal 2015, s. 254.

${ }^{21}$ Gallus 1949.

${ }^{22}$ Dr Galon był chory na gruźlicę. Podjęcie starań o wpisanie na Volkslistę było - jak można przypuszczać - spowodowane obawą o los własny i rodziny. Wiadomo z relacji świadków, że nie brał udziału w eksterminacji chorych i współpracował z polskim ruchem podziemnym, przekazując informacje o tym, co działo się w Zakładzie. W kwietniu 1940 r. został komisarycznym dyrektorem Zakładu dla chorych na gruźlicę w Gostyninie. Zob. na ten temat: Jaska i Piotrowski, brw., s. 98.

${ }^{23}$ Rieß 1995, s. 312 i n.

24 Za: Schwanke 2015a, s. 66.

${ }^{25}$ Jaksa i Piotrowski, brw, s. 100. 
und Leibesübungen), którego szefem został dr Hans Friemert. W ramach wydziału utworzono Centralne Biuro ds. Przenoszenia Chorych (Zentrale Stelle für Krankenverlegung), odpowiedzialne za przygotowanie i przeprowadzenie akcji wymordowania pacjentów szpitali psychiatrycznych oraz tajne biuro Urzędu Stanu Cywilnego, którego zadaniem było wystawianie aktów zgonu pacjentów.

Najpierw zamordowano Żydów, potem Polaków i Ukraińców. Niemcy zostali zabici lub wywiezieni z Zakładu nieco później. Oddziały V i II były ostatnimi stacjami przed uśmierceniem. Zgromadzeni tam pacjenci byli ubierani w najgorsze rzeczy i od 6.00 rano przygotowywani do transportu. Apogeum tych przegotowań stanowiło pojawienie się głównego pielęgniarza Reicha (członek SS) ze strzykawką i butelką z wodnistym płynem (zapewne skopolaminą). Duża dawka powodowała słabość, brak reakcji, pianę na ustach. Potem pacjenci byli wrzucani do podstawianych ciężarówek (często więcej osób niż miejsc) ${ }^{26}$.

W grudniu 1939 r. wywieziono 595 osób. Akcją dowodził oficer SS-Hauptsturmführer Herbert Lange, stojący na czele oddziału (Sonderkommando) utworzonego specjalnie w tym celu z polecenia wyższego dowódcy SS i policji w Kraju Warty Wilhelma Koppego oraz inspektora Policji Bezpieczeństwa (Sipo) Ernsta Damzoga $^{27}$.

Pacjenci byli wywożeni po 60-70 osób, prawdopodobnie do Fortu VII w Poznaniu, i tam uśmiercani w komorze gazowej, a następnie grzebani, prawdopodobnie w Palędziu. Niestety, dokładnego miejsca pochówku nie udało się ustalić, ponieważ pod koniec wojny Niemcy, zacierając ślady popełnionych zbrodni, wykopali i spalili ciała ${ }^{28}$.

Zagazowanie pacjentów zakładów psychiatrycznych w grudniu 1939 r. stanowiło dla władz niemieckich ważny eksperyment. Miało, w razie gdyby uznano je za sukces, zostać zastosowane także w odniesieniu do innych kategorii osób uznanych za niepożądane w nazistowskiej III Rzeszy. Zgodnie z modernistycznym paradygmatem uważano wówczas, że taki sposób zabijania byłyby najbardziej humanitarny i - co ważne - w obliczu planów podboju całej Europy - najbardziej racjonalny.

Pod koniec grudnia komora gazowa w Forcie VII została z nieznanych przyczyn zamknięta. Jednocześnie pojawiły się pojazdy do gazowania pacjentów. Wykorzystano je nie tylko do mordowania chorych z gnieźnieńskiej Dziekanki, ale także z innych zakładów psychiatrycznych w Kraju Warty i na Pomorzu. W tym samym czasie zapadła też decyzja, że gnieźnieński zakład nadal będzie przeznaczony dla chorych psychicznie. 20 grudnia Dziekanka przyjęła oficjalnie nazwę

\footnotetext{
26 Rieß 1995, s. 315.

27 Schwanke 2015a, s. 55.

28 Więcej zob. Olszewski 1971.
} 
Tiegenhof. W szpitalu pozostawało wtedy jeszcze 641 pacjentów ${ }^{29}$. Przybywali też nowi, m.in. przywożeni z innych likwidowanych zakładów w Kraju Warty. Podczas wizyty przedstawicieli Samorządu Okręgu zadecydowano o wymordowaniu także ich. Postanowiono oszczędzić tylko „Volksdeutschów” oraz dziesięciu Polaków, których uznano za „szczególnie dobrą i odpowiednią siłę roboczą" ${ }^{30}$. „Ewakuacja” pozostałych, jak eufemistycznie nazwano mord, odbyła się w styczniu 1940 r. Pojawił się wspomniany już oddział specjalny i mobilne komory gazowe, które skróciły transporty. Pierwszy z nich miał miejsce 8, a ostatni w tej serii 12 stycznia. Każdy liczył ok. 100 pacjentów. W ciągu 4 dni wywieziono i zabito 448 osób. W sumie liczba ofiar wywiezionych z zakładu w grudniu 1939 i styczniu 1940 r. wyniosła zatem 1043 osoby.

Zachowała się imienna lista z nazwiskami 693 zamordowanych pacjentów. Nie odnotowano na niej ich narodowości, a jedynie wyznanie. Było to: 426 osób wyznania rzymskokatolickiego, 94 grekokatolików, 3 prawosławnych, 36 ewangelików, 118 żydów i 1 ateista. Nie zamieszczono informacji dotyczących wyznania 15 pacjentów ${ }^{31}$. Ofiary zostały prawdopodobnie pochowane w okolicznych lasach. Również ich ciała zostały pod koniec wojny wykopane i spalone ${ }^{32}$.

Z notesów przechowywanych w Muzeum w Żabikowie, nieuwzględniających osób wywożonych, a jedynie takie, które straciły życie w Zakładzie, wynika dodatkowo, że w od września do końca grudnia 1939 zmarło jeszcze dalszych 19 pacjentów ${ }^{33}$.

\section{GNIEŹNIEŃSKI ZAKŁAD PO WŁĄCZENIU DO AKCJI T4}

Po wymordowaniu przedwojennych pacjentów Zakład Tiegenhof stał się częścią Akcji T4, jednym z wielu miejsc uśmiercania osób zakwalifikowanych jako chore psychicznie. Za początek można uznać przysłanie w lipcu 1941 r. ankiet T4, które po naniesieniu informacji o nieomal wszystkich pacjentach, zostały odesłane do centrali w Berlinie ${ }^{34}$. Dyrektor Ratka został pracownikiem T4 we wrześniu $1941 \mathrm{r}^{35}$

${ }^{29}$ Rieß, 1995, s. 317.

30 Ibidem.

${ }^{31}$ Maćkowiak 2011.

${ }^{32}$ We wrześniu 2009 r. Muzeum w Żabikowie przy udziale archeologa z Muzeum Archeologicznego w Poznaniu przeprowadziło badania sondażowe w Leśnictwie Nowaszyce potwierdzające najpierw pochówek, a następnie zatarcie śladów poprzez odkopanie zbiorowej mogiły i oczyszczenie dołu ze szczątków ludzkich.

33 Ziółkowska 2016, s. 153.

34 Za: Fiebrandt 2011, s. 210.

${ }^{35}$ Schwanke 2015a, s. 89. 
Tiegenhof nie od razu stał się jednym z nowych miejsc, w którym praktykowano pseudoeutanazję chorych psychicznie. Zapewne potrzeba było trochę czasu na przygotowania i skompletowanie personelu. Najpierw puste budynki były wykorzystywane jako obóz przejściowy. Jednocześnie zaczęto z zakładów śmierci przysyłać do Gniezna dokumenty zabijanych pacjentów. Tu zaś, w ramach akcji kamuflowania zagłady chorych psychicznie, wystawiano i rozsyłano do rodzin akty zgonu. Nie wiadomo, ile było takich fikcyjnych aktów zgonu, ale wydaje się, że całkiem sporo, skoro obok zakładu powstał dla nich fikcyjny cmentarz. Rodziny pacjentów, którzy w rzeczywistości nigdy do Gniezna nie trafili, otrzymywały informację, że ich krewny jest pochowany na tutejszym cmentarzu. W piśmie podawano kwaterę i numer grobu. Informowano też, że utrzymanie grobu kosztuje 10 marek rocznie. Rodziny nie wiedziały, że do jednego grobu przypisywano wielu zmarłych, i że ich nazwiska nawet nie znalazły się na nagrobkach ${ }^{36}$.

Jednocześnie do zakładu zaczęto przywozić pacjentów. Byli to na początku Niemcy przesiedlani ze wschodu na mocy układu Ribbentrop-Mołotow z sierpnia 1939 r. Przybywali z Galicji, Wołynia, Besarabii i krajów bałtyckich. W 1940 dotarło ich do zakładu ok. 500, w następnym roku dalszych 300 osób. Przekazywanie Niemców ze wschodu właśnie do Kraju Warty było decyzją logiczną, jako że to właśnie ta grupa miała zasiedlić ziemie polskie wcielone do Rzeszy. Warto dodać, że w Tiegenhofie znaleźli się nie tylko pacjenci już przebywający w zakładach psychiatrycznych, ale także osoby, które zostały skierowane na leczenie wskutek drobiazgowych badań rasowych i zdrowotnych, jakim poddawano przybyszów ze wschodu ${ }^{37}$.

Nieco później pensjonariuszami, a zarazem ofiarami, Tiegenhofu stali się także Niemcy, przywożeni z likwidowanych zakładów w tzw. starej Rzeszy (Altreich). Były też kolejne polskie ofiary. Ponieważ zagładę pacjentów udało się zachować w tajemnicy, okoliczna ludność traktowała zakład jako normalną placówkę psychiatryczną i w dobrej wierze nadal oddawano tam osoby z zaburzeniami. Nadal przywożono też pacjentów z innych zakładów psychiatrycznych na okupowanych ziemiach polskich. W czerwcu 1941 r., po przetransportowaniu do Gniezna pensjonariuszy z Zakładu św. Józefa w Poznaniu, ponownie pojawił się oddział Langego. Zgodnie z dokumentami, przygotowanymi tym razem nie przez personel medyczny zakładu, ale przywiezionymi przez SS-manów, transporty objęły 158 osób. Jednak - na co wskazał Enno Schwanke - z wypowiedzi Polaków zatrudnionych w Tiegenhofie wynikało, że w tym czasie mogło być nawet 12 do 15 transportów, co zdaniem tego autora oznaczać może większą od ustalonej liczbę zamordowanych ${ }^{38}$.

\footnotetext{
36 Ibidem, s. 81 i n.

37 Zob. na ten temat Fiebrandt 2011, s. 208-209.

38 Zob. Schwanke 2015a, s. 83-88.
} 
Wykorzystane przez Schwankego zeznania świadków okazały się znakomitym źródłem wiedzy o nastrojach panujących wśród polskiego personelu, którego sytuacja niewiele różniła się od sytuacji pacjentów. Dla jednych i drugich zakład stał się miejscem kaźni, porównywalnym de facto z obozem koncentracyjnym ${ }^{39}$. Byli dyscyplinowani, więzieni, zastraszani, bici. Stali się też świadkami zbrodni, choć nie byli dopuszczani do procedur medycznych. Potrafili dość precyzyjnie opisać sposoby postępowania niemieckiego personelu z pacjentami. Niestety w odniesieniu do odtwarzania konkretnych danych, w tym liczby mordowanych pacjentów, relacje te wymagają konfrontacji z dokumentami. Przeżyta trauma i stosunkowo długi okres prześladowań oraz presji nie sprzyjały precyzyjnemu zapamiętywaniu, wręcz przeciwnie - prawdopodobne były różne pomyłki i błędy. Przede wszystkim jednak zeznający nie mieli często pełnej wiedzy o tym, co działo się z chorymi, a koszmarna rzeczywistość sugerowała rozwiązania najgorsze z możliwych.

Wydaje się, że tak było właśnie w tym przypadku. Rzeczywiście w czerwcu 1941 r. z zakładu odtransportowano wielu pacjentów. Celem transportów - poza wspomnianym wywiezieniem i uśmierceniem 158 osób - nie były jednak okoliczne lasy, ale dworzec kolejowy. Włączenie zakładu w Tiegenhofie w ramy Akcji T4 zaowocowało bowiem najpierw - jak już wspomniałam - przywożeniem chorych z innych zakładów, a potem wywiezieniem dużej grupy pacjentów. Celem transportu był położony nad Soławą zakład śmierci w Bernburgu. Jednak rozbudowany system T4 sprawiał, że chorzy nie mieli tam trafić bezpośrednio. Dla lepszego ukrycia tras poszczególnych transportów i ich przeznaczenia, a także dla ułatwienia organizacji mordów, pacjenci nie byli bowiem przewożeni bezpośrednio do zakładów śmierci, ale najpierw trafiali do zakładów etapowych. Tam spędzali 3-6 tygodni, po czym byli przewożeni do zakładu docelowego i zabijani. Dla zakładu śmierci w Bernburgu takim zakładem etapowym był położony na północ od Magdeburga zakład w Uchtspringe. Tam chorzy mieli spędzić 3-6 tygodni. W lipcu i sierpniu 1941 do Uchtspringe trafiło kilka transportów z pacjentami - wśród nich było aż 547 pacjentów z Tiegenhofu, w znakomitej większości wywodzących się spośród przywiezionych do Gniezna Niemców ze wschodu ${ }^{40}$.

Wskutek wydanego przez Hitlera polecenia zakończenia akcji T4 pacjentów tych nie zdążono jednak przekazać do zakładów śmierci na zagazowanie. Pozostali zatem w zakładzie etapowym w Uchtspringe. Do końca wojny zmarła ponad połowa z przywiezionych chorych. Niewielką część z pozostałych przy życiu w 1944 r. przeniesiono do Zakładu Meseritz-Oberwalde ${ }^{41}$, a z nieco więcej niż 1/5 utworzono transport do Zakładu Hadamar, koło Frankfurtu nad Menem.

\footnotetext{
39 Zob. Na ten temat Gajewska, 2016a, s. 19-28.

40 Fiebrandt, 2011, s. 210.

${ }^{41}$ Chodzi o zakład znajdujący się w dzisiejszym Międzyrzeczu.
} 
W Hadamar do końca wojny zmarli wszyscy, w Meseritz-Oberwalde przeżyło tylko 165 osób, czyli $16 \%{ }^{42}$.

Zachowane dokumenty pokazują, że większość pacjentów deportowanych z Tiegenhofu do Hadamar stanowiły osoby od dawna przebywające w zakładach psychiatrycznych. Jedna z pacjentek przebywała w Tiegenhofie już od 1895 r. Pozostałych wcześniej przeniesiono do Gniezna z innych zakładów: Owińsk, Kościana, Gostynina i Warty ${ }^{43}$. Wydaje się, że kryterium pozostawiania poszczególnych pacjentów przy życiu była ich zdolność do pracy. Ten utylitaryzm był następstwem wspomnianej już reformy lecznictwa psychiatrycznego $z$ lat 20 . Wówczas pacjenci zdolni i chętni do pracy mogli liczyć na lepsze wyżywienie; w warunkach wojennych stawką stało się życie. Oznaczało to, że pogorszenie stanu zdrowia i utrata lub choćby osłabienie zdolności do pracy były jednoznaczne z wyrokiem śmierci.

Zakończenie pierwszej fazy Akcji T4 przypadło w Tiegenhofie na czas przejściowej zmiany dyrektora. Wiktora Ratkę, który w sierpniu 1941 r. na rok został oddelegowany do centrali w Berlinie, do komisji dokonującej selekcji w ramach akcji „14 f 13”44, zastąpił Niemiec bałtycki Wladimir Nikolajew. Wprowadzone przez niego nowe porządki pogorszyły jeszcze sytuację zarówno pacjentów, jak i resztek polskiego personelu. Jak wskazują zapiski w notesach, zaczęła też gwałtownie rosnąć liczba tracących życie pacjentów gnieźnieńskiego zakładu. O ile bowiem w roku 1940 liczba zmarłych wzrosła do 244, a w kolejnym 1941 utrzymała się na podobnym poziomie 226, to od 1942 r. nastąpił jej wzrost do $494^{45}$. Tendencja wzrostowa utrzymała się też w kolejnych dwóch latach, mimo powrotu na stanowisko dyrektora Ratki. Wiele wskazuje, że był zaufanym człowiekiem centrali T4 i że jego powrót do Gniezna wiązał się z nowymi zadaniami, jakie postawiono przed zakładem.

Wydaje się, że - wbrew temu co napisał w swej książce M. Jaska ${ }^{46}$ - od drugiej połowy 1941 r. nie było już dalszych transportów śmierci z Tiegenhofu. Postępowanie takie byłoby niezgodne z założeniami T4 po zawieszeniu akcji uśmiercania chorych za pomocą gazu. Do Zakładu coraz liczniej zwożono natomiast pacjentów psychiatrycznych z tzw. starej Rzeszy, zwłaszcza ze zbombardowanych przez aliantów miast, gdzie budynki zakładów psychiatrycznych przerabiano na tymczasowe schroniska dla osób pozbawionych dachu nad głową. W dodatku w warunkach wojennych zaczęto rozszerzać zagładę na inne kategorie osób bezużytecznych. Do psychicznie chorych dołączyli gruźlicy, uznana za krnąbrną młodzież, niezdolni

${ }^{42}$ Lilienthal 2014.

${ }^{43}$ Ibidem.

${ }^{44}$ Chodzi o akcję prowadzoną w obozach koncentracyjnych i polegającą na wychwytywaniu i przekazywaniu do zabicia chorych więźniów.

${ }^{45}$ Ziółkowka 2016, s. 153.

${ }^{46}$ Jaska i Piotrowski, brw., s. 101. 
do pracy robotnicy przymusowi, starzy ludzie cierpiący na demencję, osoby ciężko ranne $\mathrm{w}$ alianckich nalotach. Pole działania morderców rozszerzało się z roku na $\operatorname{rok}^{47}$. Nic też dziwnego, że w wielu zakładach psychiatrycznych budowano wtedy baraki, służące jako dodatkowe miejsce przetrzymywania przeznaczonych na śmierć pacjentów. W Tiegenhofie miały powstać aż dwa ${ }^{48}$.

Już w listopadzie $1941 \mathrm{r}$. w pięciu oddzielnych transportach przywieziono 400 pacjentów z Zakładów Altersdorf w Hamburgu i zakładu w Lagenhorn ${ }^{49}$. Równocześnie do zakładu dostarczono potężny transport medykamentów, a właściwie środków umożliwiających kontynuowanie zagłady. $Z$ badań przeprowadzonych przez E. Schwankego wynika, że od tego właśnie transportu w zakładzie rozpoczęło się masowe zabijanie pacjentów, już bez udziału Sonderkommando Lange ${ }^{50}$. Mordu dokonywał personel medyczny, który - jak się wydaje - nie robił już żadnych różnic między polskimi i niemieckimi pacjentami. Życie pacjentów mogła uratować zdolność i chęć do wykonywania różnych prac na rzecz zakładu - w tej fazie miała ona dużo większe znaczenie niż na początku.

O włączeniu gnieźnieńskiego zakładu w ogólnoniemiecki system zabijania osób psychicznie chorych świadczy dobitnie zorganizowanie w Tiegenhofie „specjalistycznego oddziału dziecięcego", jednego z przynajmniej 31 istniejących w całej Rzeszy. Nazwa miała - jak to słusznie zauważył Enno Schwanke - charakter eufemistyczny. „Miała ukrywać zarówno warunki, w jakich przebywali chorzy, jak i funkcję oddziałów, polegającą na opiniowaniu, selekcjonowaniu i zabijaniu"51. Utworzenie takiego oddziału w Gnieźnie świadczyło o zaufaniu centrali T4 do władz szpitala.

Decyzja o utworzeniu oddziału zapadła najpóźniej we wrześniu 1942 r. w Kancelarii Führera. Pierwsze dzieci trafiły do Tiegenhofu w lutym 1943 r. z okręgowego zakładu leczniczego w Warcie. Było to dwanaścioro dzieci pochodzenia niemieckiego. Tylko dwoje z nich dożyło do 1944 r., a tylko jedno do końca wojny ${ }^{52}$. Oddział istniał aż do stycznia 1945 r., do ucieczki Niemców z Tiegenhofu. Zgodnie z ustaleniami E. Schwankego w sumie przyjęto 138 dzieci, w wieku od 4 miesięcy do 14 lat. Większość z nich zmarła w ciągu roku, czasem w kilka miesięcy od przybycia. Do $1945 \mathrm{r}$. zmarło 88 spośród nich ${ }^{53}$. Z zeznań personelu wynika, że były zabijane za pomocą luminalu, skopolaminy i tlenku chloru. Co ciekawe, na oddział

\footnotetext{
47 Aly 2015, s. 61.

48 Ibidem, s. 257 i n.

${ }^{49}$ Zob. Schwanke 2015b, s. 176 i n.

${ }^{50}$ Ibidem, s. 177.

${ }^{51}$ E. Schwanke 2016, s. 82.

52 Ibidem, s. 86.

${ }^{53}$ Ibidem, s. 88 .
} 
trafiały dzieci niezależnie od pochodzenia - Reichs- i Volksdeutsche, a nawet - co było ewenementem w placówkach tego typu - dzieci polskie.

Liczba ofiar rosła. Jeśli wierzyć autorowi notatników z Żabikowa, w 1943 r. zmarło 417 pacjentów, a w 1944 aż $673^{54}$. Nie wiemy, czy ten wzrost spowodowany był jakąś nieznaną dyrektywą (personel niemiecki Tiegienhofu uciekł na 2 dni przed wkroczeniem do Gniezna Rosjan, zabierając ze sobą żywność i ważniejsze dokumenty ${ }^{55}$ ), kłopotami zaopatrzeniowymi czy też wynikał z działań podjętych przez Ratkę na własną rękę. W każdym z przypadków mogło chodzić o zwiększającą się liczbę chorych przywożonych do zakładu, a także o zacieranie śladów popełnionych zbrodni.

Niewiele wiemy o szczegółach życia w zakładzie - zwłaszcza zaś o tym, przez co musieli przechodzić chorzy. Źródłem wiedzy, które rzuca nieco światła na tę kwestię, są listy i wiersze jednego z pacjentów pisane do córki i odnalezione po latach przez wnuka. Heinrich Wulf trafił do Tiegenhofu w $1943 \mathrm{r}$. Został przywieziony po czterech i pół roku przebywania w zakładach w Nadrenii Północnej Westfalii. Do placówki psychiatrycznej trafił z powodu alkoholizmu. Ponieważ leczenie nie przynosiło efektów, co spowodowane było postawą pacjenta, został uznany za przewlekle chorego i jako bezużyteczny skierowany na Wschód.

Listy są lakoniczne, nie zawierają żadnych szczegółów dotyczących personelu medycznego, chorych, leczenia, co nie dziwi, biorąc pod uwagę fakt, że korespondencja była cenzurowana. Wulf napisał o tym w liście z maja 1944 r.: „Moje listy przechodzą przez cenzurę i gdybym chciał Tobie opisać całą prawdę, to list wylądowałby w koszu na papier" ${ }^{\prime 5}$. Mimo tego ograniczenia znamienne jest, że tematami najczęściej się pojawiającymi są głód i nuda. Pacjent prosi córkę o „coś przyzwoitego do jedzenia” i wspomina, że „powinien postarać się trochę przytyć, gdyż wyżywienie znów się pogorszyło" ${ }^{57}$. Poczuciu głodu towarzyszyła monotonia, wywołana bezczynnością, szczególnie dokuczliwa w niedziele i święta ${ }^{58}$.

Takie postępowanie z psychicznie chorymi nie było specyfiką Tiegenhofu, ale - od końca 1942 r. - powszechną praktyką, stosowaną w nieomal wszystkich zakładach na terytorium III Rzeszy. Wymyślono nawet specjalną niskokaloryczną dietę, która prowadziła do powolnej śmierci pacjentów. Łączyła dwa cele: oszczędność i eliminację osób uznanych za bezużyteczne dla niemieckiej wspólnoty narodowej.

Podkreślić należy, że uproszczeniem byłoby uznanie, że Tiegenhof był wyłącznie miejscem zabijania i gnębienia pacjentów. Jak zdołała ustalić Maria Fiebrandt, wskutek podwójnego powiązania, zarówno z centralą T4, jak i z władzami okręgu,

\footnotetext{
54 Ziółkowska 2016, s. 154.

55 Jaska i Piotrowski, brw, s. 110.

56 Gajewska 2016 b, s. 128.

57 Ibidem, s. 129.

58 Ibidem, s. 130.
} 
Zakład stał się jednocześnie największym w Kraju Warty szpitalem psychiatrycznym i neurologicznym, którego zadaniem było nie tylko eliminowanie chorych, ale także leczenie i prowadzenie badań naukowych. Za taką tezą o dwoistości funkcji Tiegenhofu przemawiają zarówno zachowane zamówienia na zakup drogiego sprzętu, jak i relacje personelu o stosowaniu nowoczesnych - jak na lata 40. metod leczniczych. Co ciekawe, inicjatorem wielu działań w tym zakresie był wspomniany już Nikolajew, skądinąd doktor habilitowany nauk medycznych w zakresie neurologii. To on zorganizował oddział neurologiczny, sprowadził do zakładu pompy insulinowe i aparat do elektrowstrząsów ${ }^{59}$. Wszystko to służyło zarówno pracy naukowej, jak i bardziej skutecznemu leczeniu pacjentów, co miało uczynić z Tiegenhofu wzorcowy zakład psychiatryczny. Tyle tylko, że nie leczono wszystkich, ale wyłącznie Niemców, i to tych, których uznawano za uleczalnych i wartych wyleczenia. Ponieważ kryterium zakwalifikowania do leczenia stanowiła m.in. zdolność i chęć do pracy, z procedur leczniczych wyłączani byli tzw. aspołeczni. Warto wspomnieć, że działalność naukowa była w Tiegenhofie kontynuowana także po przejściu Nikolajewa do innego zakładu w 1942 r.

Trudno dziś ustalić, która część działalności była ważniejsza i jakie były proporcje podziału pacjentów. Czy więcej było tych skazanych na eksterminację, czy też tych, których leczono? Nie wiadomo też, czy pacjenci stawali się ofiarami prowadzonych w zakładzie badań naukowych, choć informacje na ten temat płynące z innych zakładów psychiatrycznych na terenie III Rzeszy każą przypuszczać, że tak właśnie być mogło.

Za tezą o dzieleniu chorych i poddawaniu tylko części z nich eksterminacji wydają się również przemawiać liczby: fakt, że w chwili wkroczenia do zakładu żołnierzy Armii Czerwonej pozostawało tam jeszcze 1033 chorych $^{60}$, w tym 88 na „specjalistycznym oddziale dziecięcym”. Oznacza to, że zakład miał prawie pełne obłożenie.

\section{LICZBA OFIAR}

Na koniec warto zastanowić się nad rozmiarami popełnionej zbrodni. W literaturze przedmiotu pojawiają się różne liczby ofiar. Czasem są oparte na szacunkach, czasem na trudnych dziś do zweryfikowania wyliczeniach. I tak Enno Schwanke - wskazując na luki w dokumentacji - domniemywa, że łączna liczba ofiar może sięgać nawet pięciu tysięcy. Z kolei Marian Jaska, opierając się na danych J. Gallusa, pisze o 3586 ofiarach. Liczba ta jest nawet rozpisana na poszcze-

59 Fiebrandt 2016, s. 213.

60 Taką liczbę za J. Gallusem podaje M. Jaska w: Jaska i Piotrowski brw., s. 110. 
gólne lata: w 1939 r. eksterminowanych pacjentów było - jego zdaniem - 595, w następnym roku 1940 - 448, a w roku 1941 - 158. To liczby pacjentów wywiezionych i zamordowanych poza zakładem. W 1942 r. - zdaniem Jaski - zamordowano 499 pacjentów, a w 1943 aż 1956. Potem do końca wojny miało nie być dalszych ofiar $^{61}$. Liczba 3586 ofiar powtarzana jest przez autorów polskich ${ }^{62}$; znalazła się też na stronie internetowej Dziekanki ${ }^{63}$.

Przytoczone liczby wydają się sugerować, że chodzi wyłącznie o wywożenie pacjentów poza teren zakładu i uśmiercanie. Tak jest w przypadku danych za lata 1939-1941. Nie wiadomo, na czym oparto dane dotyczące lat 1942-1945. Wydają się one jednak mocno wątpliwe, ponieważ śladów po takich transportach nie udało się odnaleźć ani w niemieckich archiwach, ani też w zeznaniach personelu. Warto też zauważyć, że liczby te wydają się nie uwzględniać pacjentów zamordowanych w zakładzie.

Z kolei notesy z Żabikowa zawierają notatki o śmierci 2118 pacjentów Dziekanki/Tiegenhofu. Do tego należy jeszcze dodać tych, którzy zostali wywiezieni w transportach z 1939, 1940 i 1941 r. i zagazowani. Było ich łącznie 1201, i są to morderstwa najlepiej udokumentowane. Oznaczałoby to, że łączna liczba ofiar wyniosła 3319 osób. Także i to wyliczenie, nawet przy założeniu rzetelności uwzględnionych danych, nie może jednak być traktowane jako ostateczna liczba ofiar.

Złożoność przyjętych procedur i różnorodność środków kamuflujących zagładę chorych psychicznie, a także brak pełnej dokumentacji uniemożliwiają po wielu latach wyciąganie jakiś kategorycznych wniosków w tej sprawie. Nawet dokumenty Urzędu Stanu Cywilnego nie wyjaśniają - zwłaszcza w odniesieniu do drugiej fazy zagłady - kto został zamordowany, a kto zmarł śmiercią naturalną. Zachowane dokumenty medyczne (a raczej ich resztki) nie zawierają informacji o głodzeniu, zaniedbywaniu lub podawaniu pacjentom nadmiernych dawek leków. Pisano natomiast $\mathrm{z}$ reguły, że chorzy zmarli na tyfus, szkarlatynę czy czerwonkę. A informacje o dolegliwościach czy ewentualnych terapiach, jakim byli poddawani, są mało wiarygodne i niemożliwe do zweryfikowania.

Do tego dochodzą jeszcze pacjenci wywiezieni do innych zakładów i tam uśmierceni. Są oni przecież, przynajmniej pośrednio, również ofiarami Tiegenhofu. Udało się ustalić dane jednego tylko transportu: z $1941 \mathrm{r}$. Mogły jednak być także inne, ponieważ transportowanie pacjentów psychiatrycznych było w III Rzeszy częste, był to ważny element postępowania z tą grupą chorych i zarazem kamuflowania ich mordowania.

\footnotetext{
61 Ibidem, s. 101.

62 Zob. choćby Gaweł 2011, s. 201.

63 Dziekanka 2020.
} 
Niemożliwe jest też wyciąganie wniosków z przedwojennych danych statystycznych. Nowi pacjenci byli przecież często przekazywani do Tiegenhofu właśnie dlatego, że byli uznani za nieuleczalnie chorych. Trafiali do zakładu po długiej i trudnej podróży, w miejsce odległe od stron ojczystych i rodzin, co musiało dodatkowo pogarszać ich stan psychiczny i fizyczny. Mogło też przyczynić się do wzrostu śmiertelności.

\section{DZIEKANKA/TIEGENHOF: STATE OF KNOWLEDGE CONCERNING THE OPERATION OF THE INSTITUTION DURING WORLD WAR II}

\section{Summary}

The article presents the state of research on the history of the mental institution known as Dziekanka during World War II. New information discovered by German authors and increasing knowledge about the course of Aktion T4 makes it possible to verify erroneous findings and contributes new elements to the overall picture. For instance, it is demonstrated that not all of the murdered patients lost their lives as part of Aktion T4, or that - despite the claims of certain Polish authors Tiegenhof was also a site where treatment and research did take place. The paper offers an overview of literature concerned with Dziekanka/Tiegenhof, discusses extermination of its patients, the individuals responsible and the connection with Aktion T4, as well as the significance of the institution in the Warthegau province; the question of the number of victims is also addressed.

\section{Bibliografia}

Aly G. 2015, Obciążeni: Eutanazja w nazistowskich Niemczech, Wołowiec.

Fiebrandt M. 2011, NS-Bevölkerungspolitik und Psychiatrie. Die Umfunktionierung der Heilanstalt Tiegenhof/Dziekanka zu einer „Vorbildlichen Heilanstalt für Deutsche“ während der Deutschen Besatzungszeit 1939-1945, [w:] Łukomski i Kucharski (red.), Medycyna na usługach systemu eksterminacji ludności w Trzeciej Rzeszy i na terenach okupowanej Polski, Poznań-Gniezno, s. 205-216.

Gajewska G., Tomczak M., Musielak M. i in. 2016, Bezużyteczni. Studia nad losami chorych i upośledzonych psychicznie w okresie rządów nazistowskich, Gniezno.

Gajewska G. 2016a, „Nagie życie” w zakładach dla psychicznie i nerwowo chorych pod rządami nazistów, [w:] Gajewska G., Tomczak M. i in., Bezużyteczni. Studia nad losami chorych i upośledzonych psychicznie w okresie rządów nazistowskich, Gniezno, s. 19-28.

Gajewska G.2016b, „Kochana córko” - świadectwo pacjenta szpitala Tiegenhof Heinricha Wulfa, [w:] Gajewska G., Tomczak M. i in., Bezużyteczni. Studia nad losami chorych i upośledzonych psychicznie w okresie rządów nazistowskich, Gniezno, s. 121-137.

Gallus J. 1949, Dziekanka w latach 1939-45 oraz jej udział i rola w wyniszczaniu umysłowo chorych Polaków, Rocznik Psychiatryczny 37, 1.

Gaweł R. 2011, Zakład psychiatryczny w Dziekance w okresie II wojny światowej, [w:] Łukomski G., Kucharski G. (red.), Medycyna na usługach systemu eksterminacji ludności w Trzeciej Rzeszy i na terenach okupowanej Polski, Poznań-Gniezno, s. 197-203. 
Jaroszewski Z. (red.) 1993, Zagłada chorych psychicznie w Polsce 1939-1945, Die Ermordung der Geisteskranken in Polen 1939-1945, Warszawa.

Jaska M., Piotrowski A. brw., Dzieje Wojewódzkiego Szpitala dla nerwowo i psychicznie chorych im. Aleksandra Piotrowskiego „Dziekanka” w Gnieźnie 1894-1994, b.m.w.

Lilienthal G. 2014, Die Euthanasie der psychisch Kranken mit besonderer Berücksichtigung der Patienenten von Tiegenhof/Dziekanka, referat wygłoszony podczas konferencji „Nazistowska medycyna w okupowanej Polsce. Ideowe, prawne i ekonomiczne aspekty Akcji T4 w Kraju Warty”, zorganizowanej w Gnieźnie 13-14 maja 2014.

Lilienthal G. 2015, Polskie ofiary nazistowskiej eutanazji w Hadamar (1942-1945), [w:] Musielak M., Głodowska K.B. (red.), Medycyna w cieniu nazizmu, Poznań 2015, s. 248-256.

Łukomski G., Kucharski G. (red.) 2011, Medycyna na usługach systemu eksterminacji ludności w Trzeciej Rzeszy i na terenach okupowanej Polski, Poznań-Gniezno.

Maćkowiak M 2011, Tiegenhof, Materiały edukacyjne Muzeum Martyrologicznego w Żabikowie, Luboń.

Musielak M., Głodkowska K.B. (red.), 2014, Opieka pielęgniarska w czasach nazizmu. Wybrane problemy i kazusy, Poznań.

Musielak M. 2014, Ruch higieny ras a system ochrony zdrowia w Trzeciej Rzeszy, [w:] Musielak M., Głodowska K.B (red.), Opieka pielęgniarska w czasach nazizmu. Wybrane problemy i kazusy, Poznań, s. 13-25.

Musielak M., Głodowska K.B. (red.) 2015, Medycyna w cieniu nazizmu, Poznań.

Nasierowski T., Herczyńska G., Myszka D.M. (red.), 2012, Zagłada chorych psychicznie. Pamięć i historia, Warszawa.

Olszewski M. 1971, Fort VII w Poznaniu, Poznań.

Rieß V. 1995, Die Anfänge der Vernichtung „lebensunwertes Lebens” in den Reichsgauen DanzigWestpreußen und Wartheland 1939/40, Frankfurt a.M.

Schmuhl H.-W. 2000, Zreformowana psychiatria a masowa zagłada, [w:] Nazizm, Trzecia Rzesza a procesy modernizacji, Wybór i opracowanie H. Orłowski, tłum. M. Tomczak, Poznań, s. 381418.

Schwanke E. 2015a, Die Landesheil- und Pflegeanstalt Tiegenhof. Die nationalsozialistische Euthanasie in Polen während des Zweiten Weltkrieges, Frankfurt a.M.

Schwanke E. 2015b, Okręgowy zakład opieki w Tiegenhof (Dziekanka), [w:] Musielak M., Głodowska K.B. (red.), Medycyna w cieniu nazizmu, Poznań, s. 168-183.

Schwanke E. 2016, „Specjalistyczny oddział dziecięcy” szpitala Tiegenhof (Dziekanka). O połączeniu środków z zakresu higieny rasowej i rasistowskiej polityki narodowej w okręgu Kraj Warty, [w:] Gajewska G., Tomczak M. i in. Bezużyteczni. Studia nad losami chorych i upośledzonych psychicznie w okresie rządów nazistowskich, Gniezno, s. 79-90.

Tomczak M. 2016, Kościoły w Niemczech wobec pseudoeutanazji chorych psychicznie, [w:] Gajewska G., Tomczak M. i in., Bezużyteczni. Studia nad losami chorych i upośledzonych psychicznie w okresie rządów nazistowskich, Gniezno, s. 45-62.

Ziółkowka A. 2016, Notesy z Dziekanki/Tiegenhofu, [w:], Gajewska G., Tomczak M. i in., Bezużyteczni. Studia nad losami chorych i upośledzonych psychicznie w okresie rządów nazistowskich, Gniezno, s. 153-4. 